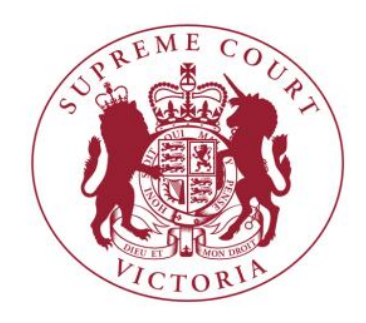

\title{
PRE-TRIAL MANAGEMENT OF EXPERT EVIDENCE IN THE KILMORE EAST BUSHFIRE PROCEEDING
}

\author{
SIMON MCKENZIE*
}

This paper, the first in a series on the management of expert evidence during the Kilmore East bushfire proceeding, considers the pre-trial management of experts. This case was the largest class action in Victoria's history, and expert evidence played a central role. Despite the volume and complexity of this evidence, the Court in this proceeding was not particularly interventionist in the management of experts prior to trial. This paper considers whether the management of experts by the Court prior to trial usefully contributed to running of the proceeding. It records the reflections of a range of participants in the proceeding, including the presiding judge, barristers and solicitors. This material was gathered in interviews conducted after the case settled. While the judges thought a more hands-on approach by the Court in the selection and briefing of experts would have been reduced the volume of expert evidence, the legal practitioners were not convinced that this kind of intervention would be useful. They noted how difficult it would be for the Court to choose the best experts and navigate disputes between experts about the appropriate methodology for developing their evidence. This is not to say that some intervention is not useful, and the participants in the Kilmore East bushfire proceeding identified a number of procedures that could be adopted to improve the effectiveness of the expert evidence. This paper considers some of these proposals, such as case management conferences and increased sharing of information between parties about the expert evidence they will be using in the proceeding.

\footnotetext{
${ }^{*}$ BA, LLB (Hons) (Tas); Senior Fellow (Melbourne Law Masters) and PhD Candidate at the University of Melbourne. The support of Justice Rita Zammit and Justice Jack Forrest was invaluable in carrying out this research project. In addition, the assistance and advice of Gary Cazalet at the University of Melbourne as well as Stuart Moran and Katrina Chow at the Supreme Court of Victoria are gratefully acknowledged. The Supreme Court of Victoria funded this research.
}

This paper was published on 13 April 2016. 


\section{CONTENTS}

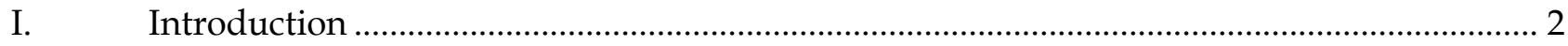

II. Snapshot of issues regarding the pre-trial management of experts..................................... 4

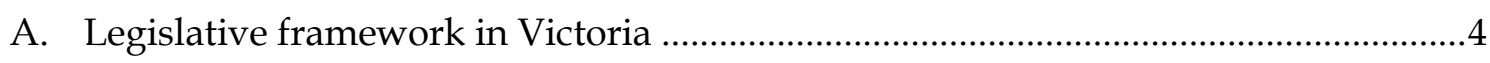

B. Overview of literature on pre-trial management of experts .......................................5

III. Experts in the Kilmore East bushfire proceedings ................................................................ 7

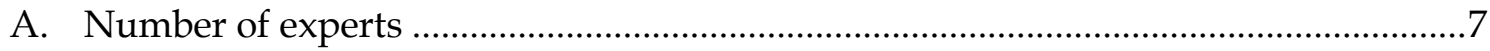

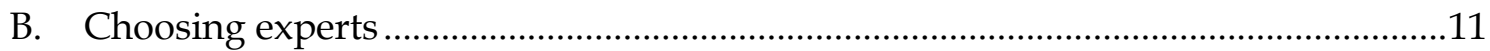

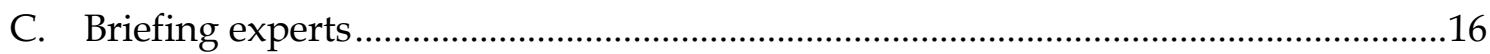

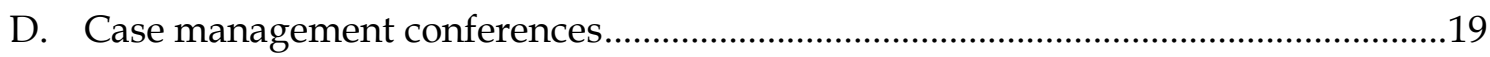

IV. Pre-trial management: concluding remarks ....................................................................... 24

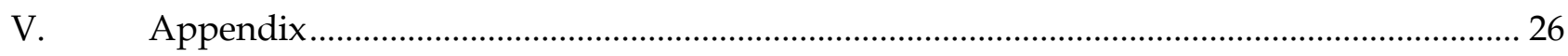

A. Section one: view from the Victorian bench ...............................................................26

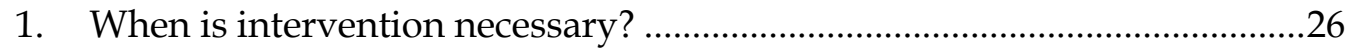

2. General considerations for the management of experts prior to trial ........28

3. Case Management Conferences .....................................................................30

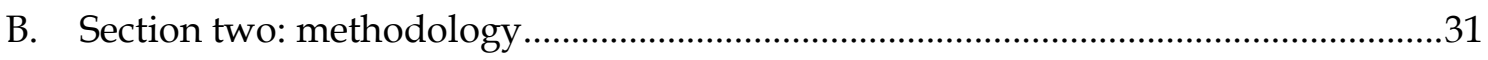

\section{INTRODUCTION}

Matthews $v$ SPI Electricity Pty Ltd (the 'Kilmore East bushfire proceeding') was the largest civil trial in the history of Victoria. It was one of the cases arising from the devastating 'Black Saturday' bushfires of 7 February 2009. The direct cause of the Kilmore East bushfire was common ground at the trial: the parties all accepted that it started when a section of power line broke and upon striking the ground, ignited a fire. ${ }^{1}$ It was an extremely hot and windy day after a hot and dry summer, and the conditions allowed the fire to spread rapidly. It eventually killed 119 people, injured more than 1,000, and damaged or destroyed approximately 1,772 homes and properties. ${ }^{2}$ One of the notable features of the trial was the role that expert evidence played in the proceedings, and the number of experts - 40 in total - called to provide evidence. The Supreme Court of Victoria commissioned a research project into the management of expert evidence in the proceeding, and in particular to capture the experience and reflections of the participants in the

\footnotetext{
${ }^{1}$ Matthews v AusNet Electricity Services Pty Ltd[2014] VSC 663, [1]-[9].

${ }^{2}$ Ibid [7].
} 
proceeding. This is the first in a series of four papers, and considers the pre-trial management of experts.

The primary material for the paper was gathered in interviews with some of the judges, barristers and solicitors involved in the proceeding. They record the reflections of the participants about the decisions they made about the management of experts prior to the commencement of the trial. In addition, the interviews also canvassed a number of other issues: the possibility of limiting the number of experts; the appropriate role for the court in choosing and briefing experts; the level of disclosure between the parties about the choice of expert and the material used to brief them; and the value of case management conferences. The participants had differing views on what impact, if any, a more interventionist court would have had on the pre-trial management of experts. Generally speaking, Justice Jack Forrest and Associate Justice Rita Zammit ${ }^{3}$ thought that a more hands-on approach could have reduced some of the procedural issues that arose as a result of the large number of experts. The legal practitioners were much more sceptical about an expanded role for the Court.

Before turning to the material gathered from the interviews, the first section of the paper provides a brief outline of the legislative regime in place in Victoria dealing with the pre-trial management of expert evidence, as well as a brief overview of the relevant literature. This overview is not comprehensive, but includes a review of Law Reform Commission reports as well as other relevant sources. It identifies some of the factors judges and academics look to when assessing the necessity of pre-trial intervention.

It is important to note that this paper does not intend to offer any 'perfect' or 'ideal' way for a court to manage experts prior to trial. Each case will have unique features, and it is important that courts are responsive to the circumstances of the matter before them. Therefore, a degree of flexibility is desirable. The paper seeks to identify some successes of the Court's approach in the Kilmore East bushfire proceeding, as well as to recognise some of the concerns raised by the participants. The aim of the paper, and the research project generally, is to assist judges and lawyers involved in large cases in the future by setting out record of what happened, from a procedural perspective, during these significant proceedings.

This paper has an appendix that provides some context and further background for this research. The first section sets out the view on the pre-trial management of expert evidence of four Victorian judges who were not involved in the Kilmore East bushfire proceeding. This material was

\footnotetext{
${ }^{3}$ While at the time of the proceeding and interviews conducted for this research project she was an associate justice, Justice Zammit was appointed a judge of the Supreme Court Trial Division in February 2015.
} 
gathered in interviews in late 2014, and shows some of the different judicial perspectives on the pre-trial management of experts. The second section sets out the methodology of the paper.

\section{SNAPSHOT OF ISSUES REGARDING THE PRE-TRIAL MANAGEMENT OF EXPERTS}

\section{A. Legislative framework in Victoria}

The Victorian Supreme Court has significant power to manage how parties use experts in the pretrial phase of the proceedings. The wide range of management options available to the Court allows Judges to give parties as much or as little autonomy over appointing experts as is necessary to ensure that the process is just and efficient. It is important to note that the following legislative framework was not in place when the Kilmore East bushfire proceeding commenced in 2009, and the powers available to the Court were not as clear as they are now. Nevertheless, it is useful to set out what a court can currently do to manage expert witnesses.

Section 65G(1) of the Civil Procedure Act 2010 ('the Act') requires that unless the court otherwise orders, a party must seek the direction of the court "as soon as practicable" if the party intends to adduce expert evidence at trial, or becomes aware that it may adduce expert evidence. Section $65 \mathrm{H}$ grants very wide powers to the Court in the lead up to the trial to manage how expert evidence is used. It provides:

1) A court may give any directions it considers appropriate in relation to expert evidence in the proceeding.

2) A direction under subsection (1) may include, but is not limited to -

a) The preparation of the expert's report;

b) The time for service of an expert's report;

c) Limiting expert evidence to specified issues;

d) Providing that expert evidence may not be adduced on specified issues;

e) Limiting the number of expert witnesses who may be called to give evidence on a specified issue;

f) Providing for the appointment of -

i. Single joint experts; or

ii. Court appointed experts;

g) Any other direction that may assist an expert witness in the exercise of his or her functions as an expert witness in the proceeding.

3) Any direction under subsection (1) may be given at any time in a proceeding. ${ }^{4}$

\footnotetext{
${ }^{4}$ Civil Procedure Act 2010 (Vic).
} 
As is clear, the powers granted to the Court by the above section gives the judge a broad framework within which to deal with experts. The Explanatory Memorandum for the 2012 Bill explained the purpose of s 65G:

This section emphasises the important role of the courts in determining the most effective and proportionate use of expert evidence from an early stage of the proceeding, rather than leaving it solely to the parties to determine. ${ }^{5}$

It goes on to explain that s $65 \mathrm{H}$ :

... provides that a court may at any time give any direction that it considers appropriate in relation to expert evidence. This makes it clear that the courts have the power to give appropriate directions and impose reasonable limits in actively managing and controlling expert evidence. ${ }^{6}$

Victorian courts therefore have a considerable amount of leeway in managing expert evidence. As the above sections came into force shortly prior to the commencement of the trial, the pre-trial directions may have been different had these powers been available in the two years preceding the trial.

\section{B. Overview of literature on pre-trial management of experts}

In its 2005 report on expert witnesses, the New South Wales Law Reform Commission addressed the expected benefits of active judicial management of experts. One of the most striking recommendations of the Commission was a proposal that parties should be required to get the permission of the Court before leading expert evidence. ${ }^{7}$ While this recommendation was not adopted by the Victorian Parliament, it gives an indication of the aims of promoting more active management of trials by judges. The Commission explained:

... Australia has participated in the widespread trend referred to by Zuckerman as the "shift towards the imposition of a stronger control by the judges over the progress of civil litigation." Much effort by judicial officers and other court personnel now goes into "case management". In general, the courts are actively involved in making a variety of pre-trial orders associated with the preparation of the case for trial. The primary goals of case management are to minimise delay and reduce public and private costs. The new activism is intended to assist early settlement of cases, by ensuring that mediation or other dispute settlement mechanisms are available, and that the real issues in dispute are identified as clearly and as early as possible. [...] The close scrutiny of the preparation of the case for trial is designed to ensure, as far as possible, that evidence is available on

\footnotetext{
${ }^{5}$ Explanatory Memorandum, Civil Procedure Amendment Bill 2012.

${ }^{6}$ Ibid.

${ }^{7}$ New South Wales Law Reform Commission, Expert Witnesses, Report No 109 (2005), 6.1-6.11.
} 
time and cases are not adjourned because a party is taken by surprise at the last moment, and that the issues have been clearly defined so that time is not wasted with irrelevant or marginally relevant evidence. ${ }^{8}$

It is thought that a more interventionist approach to pre-trial management by Courts will "have a moderating effect on the excesses of the warring parties", particularly during megalitigation. ${ }^{9}$ Such intervention is rarely straightforward; Justice Ronald Sackville of the Federal Court of Australia, while being supportive of increased judicial intervention into the pre-trial management during mega-litigation, noted that:

The fundamental difficulty facing a court in seeking to exercise stringent control over the use of expert evidence in mega-litigation is the information-deficit. [...] [T] he most diligent judge cannot know in advance anything like as much about a party's case as that party's legal representatives. ${ }^{10}$

It is thought by some that active pre-trial management of experts can help reduce the risk of biased experts who are tainted by their relationship to the party that retained them. ${ }^{11}$ Edmond has written that the view that judges can reliably assess the bias of scientific experts is more fraught than is usually recognised.12 This opinion is not universally shared, and some judges and practitioners view this risk is overstated. Judge Michael Rackermann of the District Court of Queensland, wrote that in his experience it rarely happened and that when it does it was obvious and could be dealt with. He explained that:

The contention that expert opinions are able to be bought and sold is an inaccurate generalisation. It is also an unseemly one involving, as it does, a suggestion by lawyers that professionals of other disciplines are little more than 'paid liars'. There are those who regard such an allegation, coming from the mouths of lawyers, as somewhat ironic. Lawyers are not the only ones with professional ethics. ${ }^{13}$

With the new legislation, courts in Victoria are able to control how many experts the parties call in the case, with even the possibility of only permitting a single expert give evidence in a case. Justice Allsop, the then President of the New South Wales Court of Appeal, warned of the dangers of this

\footnotetext{
${ }^{8}$ Ibid, 6.6.

9 Justice Ronald Sackville, 'Mega-Litigation: Towards a New Approach', speech given to the Supreme Court of New South Wales Annual Conference, 17-19 August 2007, Central Coast, New South Wales.

${ }^{10}$ Justice Ronald Sackville, 'Expert Evidence in the Managerial Age', paper given to the Forensic Accounting Conference, Friday 14 March 2008, Sydney.

${ }^{11}$ See New South Wales Law Reform Commission, Expert Witnesses, Report No 109 (2005); Justice Ronald Sackville, 'Expert Evidence in the Managerial Age', above n 10.

${ }^{12}$ Gary Edmond, 'Judging Surveys: Experts, Empirical Evidence and Law Reform' (2005) 33(1) Federal Law Review 95.

${ }^{13}$ Judge Michael Rackemann, 'The management of experts' (2011) 21 JJA 168, 170.
} 
approach in competition cases, ${ }^{14}$ saying that as the expert evidence in those cases is generally about economics, and as economics is a social science where the evidence is "argumentative and contestable", ordering a single expert is problematic.15 However, where "the relevant field is relatively stable in principle and technique (such as the valuation of land) the choice of a single expert may go a long way to determine the answer to the question under consideration." 16 Similarly, Judge Rackermann notes that a serious limitation of the single-expert model is that it deprives the judge of competing views, and its usefulness is "generally restricted to circumstances where the exercise to be carried out is unlikely to be controversial." 17

\section{EXPERTS IN THE KILMORE EAST BUSHFIRE PROCEEDINGS}

The Kilmore East bushfire proceeding dealt with very complex expert evidence. The experts were called to give evidence on six important factual issues: the ignition of the fire; the failure of the conductor; power network asset management; the impact of prescribed burning; the impact of fire suppression; and warnings. The most difficult of these from a scientific perspective was the failure of the conductor, which required qualitative and quantitative evidence from physicists and industry experts. The volume of expert evidence required the Court and the parties to confront a number of difficult procedural questions prior to the trial. How should experts be chosen, and should any limit be placed on how experts gave evidence to the Court? Is it better for the parties to control the process (which is what happened in these proceedings), or would it have been better if the trial judge, Justice J Forrest, had more closely managed the process of choosing experts, or even chosen the experts himself? Once the experts were selected, should they have received a briefing from the Court prior to providing their report, and should there have been full disclosure about how the experts were briefed and the material they saw? Were directions hearings the best way to resolve these procedural questions, or were case management conferences preferable? This paper explores the different responses some of the participants had to each of these questions.

\footnotetext{
${ }^{14}$ Justice James Allsop, 'The judicial disposition of competition cases' (2010) 17 Competition \& Consumer Law Journal 241-2.

${ }^{15}$ Ibid 242. Justice Garry Downes, President of the AAT, made a similar point in 'Problems with expert evidence: Are single or court-appointed experts the answer?' (2006) 15 JJA 185.

${ }^{16}$ Ibid 242; Justice Downes added at 187 that single experts are appropriate if it is a question to which there "only one answer."

${ }^{17}$ Judge Rackemann, 'The management of experts', above n 13.
} 


\section{A. Number of experts}

It was apparent from an early stage of the Kilmore East bushfire proceeding that expert evidence would be critical, and there would be many experts called on a wide range of matters relevant to liability. One solicitor explained:

[I]t was apparent to us reasonably early that it was going to be a complex metallurgical case involving evidence from some of the leading scientists in their field. Even though we knew that, we didn't know quite how complex it would be because each time we would present an assumed factual outline to the expert as to what happened, there would be a corresponding answer which would tend to take it into a new scientific field. ${ }^{18}$

Both barristers interviewed as part of this research ${ }^{19}$ said that general mass tort claims involved a substantial amount of expert evidence and the parties knew from the outset that this case was going to require a substantial number of experts. ${ }^{20}$ In addition, one barrister pointed out that the economics of class actions made it more likely that the parties would decide to go to the expense of expansive expert evidence:

In other words, if you've just got a one off individual claim of $\$ 50,000$ you're not going to go off and spend half a million on expert evidence. But, if you've got a class action where you've got hundreds, if not thousands of claims, and you've got a total quantum of $\$ 20 \mathrm{~m}$ through to $\$ 2$ billion or something, the cost benefit analysis means that parties are going to look at expert evidence if that's at all relevant ${ }^{21}$

The Royal Commission into the 2009 Black Saturday Bushfires also provided an indication of what the expert evidence would cover. ${ }^{22}$ Associate Justice Zammit said this "gave a flavour" of the matters that would be before the Court, making it clear the scope of expert evidence would be broad. ${ }^{23}$ Both barristers agreed, saying the Royal Commission helped them appreciate the scope of the case. ${ }^{24}$ One said it was used as a "fact finding exercise for the lawyers on both sides" and was "helpful in giving us some early insight into the kinds of problems we were likely to be dealing

\footnotetext{
${ }^{18}$ Interview with solicitor involved in proceeding (20 February 2015, Melbourne) ('Interview with solicitor A').

${ }^{19}$ One barrister was from the plaintiff side, the other was from the defendant side. See the Methodology section of the appendix for further detail.

${ }^{20}$ Interview with barrister involved in proceeding (Morning of 24 February 2015, Melbourne) ('Interview with barrister A'); Interview with barrister involved in proceeding (Afternoon of 24 February 2015, Melbourne) ('Interview with barrister B').

${ }^{21}$ Interview with barrister B, above n 20.

${ }^{22}$ See Victoria, 2009 Victorian Bushfires Royal Commission, Final Report (2010).

${ }^{23}$ Interview with Associate Justice Zammit (13 August 2014, Supreme Court of Victoria, Melbourne).

${ }^{24}$ Interview with barrister A, above n 20; Interview with barrister B, above n 20.
} 
with in the litigation." ${ }^{25}$ However, he said that the scale of the Supreme Court trial was entirely different:

You can't compare the Supreme Court trial to the Royal Commission. In terms of the discipline, and the level of interrogation, the Supreme Court was just on a different scale compared to the Royal Commission. It was much, much more intensive in the court. But, the point is that because of the Royal Commission we knew from the start with the Supreme Court case that we were likely to having to deal with, just in our case, 10 or 12 different topics for experts. ${ }^{26}$

Once the proceeding had commenced, the documents filed by the parties also indicated the volume of expert evidence would be substantial. Associate Justice Zammit said the pleadings showed that "liability issues were going to be of a very technical nature" and would therefore require different experts from different areas. Justice Forrest said that it became obvious there would be very large number of experts involved in the proceeding when the parties filed the expert reports with the Court. ${ }^{27}$

The expert evidence did not remain static after the filing the report. One solicitor said that the areas of expertise and complexity of the evidence evolved over the course of the proceeding. He said this occurred "largely in response to the reports produced prior and as part of the conclave process" by the experts of another party, and this continued right up until the start of the concurrent evidence. ${ }^{28}$

Since the recent reforms to the Victorian Civil Procedure Act 201029, a judge clearly has the power to limit the number of experts called and the topics on which they are to provide evidence. ${ }^{30}$ As Justice Forrest noted, this was not an option available to him at the beginning of the Kilmore East bushfire proceeding. He said that if it were, he would have more tightly controlled the number of experts. ${ }^{31}$ He said:

Certainly on the issue as to what caused the fracture of the piece of wire that led to the bushfire I would have limited the number of experts. We had a concurrent evidence session of 10 or 11 experts, which was far too many. I endeavoured to encourage the parties to reduce their numbers. [One party] complied in general terms but the [other party] did not. That meant that I had to decide

\footnotetext{
${ }^{25}$ Interview with barrister A, above n 20.

${ }^{26}$ Ibid.

${ }^{27}$ Interview with Justice J Forrest (8 August 2014, Supreme Court of Victoria, Melbourne).

${ }^{28}$ Interview with solicitor involved in proceeding (9 June 2015, by letter) ('Interview with solicitor B').

${ }^{29}$ The relevant parts of the Civil Procedure Act 2010 were amended in December 2012 by the Civil Procedure Amendment Act 2012.

${ }^{30}$ See the first section of the appendix to this paper for further information.

${ }^{31}$ Interview with Justice J Forrest, above n 27.
} 
whether to limit them using a general discretion and I was dubious as to whether I should do so. Certainly now, with the changes to the Act, I would be far more confident. ${ }^{32}$

Justice Forrest said that he thought that in almost all cases the parties should be limited in the number of experts they call to provide evidence on a certain issue. ${ }^{33}$ Associate Justice Zammit was also in favour of limiting the number of experts in proceedings:

Narrowing down the number of expert witnesses I think is something that again should be done front-end rather than parties being allowed to call as many witnesses as they want on a particular topic. They should be required to say you get one or you get two and that's it. Again, because it avoids - you put ten people in a room they're all going to have a different view. ${ }^{34}$

The practitioners were much more cautious about this possibility. The complexity of the material meant that limiting the number of experts called on a particular issue could prevent the Court from properly understanding the scientific evidence, and the different nuances in expertise. The Kilmore East bushfire proceeding is a good example of this: there was a division between experts who were 'quantitative' and experts who were 'qualitative'; the lab-based experimental physicists, and the experts who had worked in the field for many years. Even though these experts were all experts in metallurgy, they brought substantially different kinds of expertise to the Court. One solicitor explained:

It is very hard to circumscribe the number of experts because they all have nuanced expertise. So, translating into law, there might be someone who is expert on State powers, Commonwealth constitutional powers, and human rights - so you could call three different experts, by and large speaking to the same topic from different perspectives.

[This shows] the idea that you can simply say I'm going to allow you to have one metallurgist, for example, would miss the point, because within metallurgy we quickly learnt that there were the people that were really specialised in fracture mechanics and people that really do not know very much about it. [...] [T] he idea that you can say "here's the discipline" and confine it to one [is problematic] - in fairness to the judge, he tried to achieve that, and to varying extents people worked around him, because they would choose someone who was a metallurgist but had lots of field expertise. So, their discipline was yes, he's a metallurgist, but not in a quantitative sense, he's

\footnotetext{
${ }^{32}$ Ibid.

33 Ibid.

${ }^{34}$ Interview with Associate Justice Zammit, above n 23.
} 
got some qualitative qualifications in the field to bring to bear. So it's hard for the Court to say 'no you can't call that person', even though you're talking about essentially the same discipline. ${ }^{35}$

One barrister said that it would have been problematic for the Court to be deciding on a number of experts with such a complex matter "like fracture mechanics on power lines, [where] about $90 \%$ of [...] [the] current learning on that topic was developed in the course of this litigation in order for the experts to be giving their evidence." 36

The other barrister said that in large cases involving complex causation, it would be unlikely that the court could only appoint one expert, but could find it had to find and select a number of experts. ${ }^{37}$ The barristers thought that multiple experts assist the fact-finding process by allowing for dialogue and debate to take place between the experts, which in turn allows the court to better assess the evidence. One barrister explained:

Where you've got a scientific question which is a live issue in a class action, you usually are at the cutting edge of a particular scientific area or its application, and you have competing paradigms. So as you say, there's no one objective truth that's somehow instilled in the one court appointed expert who's out there and going to give a neutral view - it's just not possible. As I was saying, you might find an expert, but if he or she is expert enough, they're likely to have committed themselves to a particular area, which then entrenches a particular bias for or against one of the parties, which is quite unsatisfactory. [...] So, as I say, other than in the most simple case where the scientific theories are pretty well established and agreed to, and all that you've got are a mechanistic application of the science, if you've got something simple like that you might have a court appointed expert but not otherwise. ${ }^{38}$

The Kilmore East bushfire proceeding was a case where it was possible to tell from relatively early on that a significant amount of expert evidence was going to be required. While limiting the number of experts might have reduced the amount of evidence the Court had to grapple with, this can be a risky approach where the relevant scientific discipline is unclear or underdeveloped. A limit on numbers is a blunt instrument that could, on occasion, leave a party in a position where they could not provide an accurate view to the Court of the all the evidentiary complexity and nuance of the case. Nevertheless, if the areas of expertise can be identified with sufficient clarity, it is something that should be considered.

\footnotetext{
${ }^{35}$ Interview with solicitor A, above n 18.

${ }^{36}$ Interview with barrister A, above $\mathrm{n} 20$.

${ }^{37}$ Interview with barrister B, above $\mathrm{n} 20$.

${ }^{38}$ Ibid.
} 


\section{B. Choosing experts}

The parties had complete autonomy as to how they chose their experts prior to the trial. One solicitor set out the efforts his team undertook to find experts:

[W]e try to find the best expert, and we have a strong preference for that person to be in Australia, but sometimes they're not. Normally once we have identified a discipline, we will do a thorough search and try to identify the 20 best people in the world, wherever they are located. We tend to interview the top five to eight to check whether their expertise lines up with their $\mathrm{CV}$, and as best you can tell as a lawyer.

$[\ldots]$

The hours that are spent identifying the right person for the actual critical question - $[\ldots]$ I'm not sure how close even senior counsel get to [understand] that. Very often they'll say "that person will stack up" or not, but they haven't realised that behind there there's a schedule of the 20 best people, and careful analysis of their criteria, detailed research about whether they've given expert evidence before, and whether it has been accepted, and therefore whether they are going to be useful. It is really hard on the parties to circumscribe that [by having court-appointed experts]. ${ }^{39}$

He said it was not just a lawyer's exercise, and that they worked with their clients to identify the leaders in the field. He said that "[t]he client quite often brings industry know-how that wouldn't be accessible to the courts." 40 All of the legal practitioners acknowledged that choosing experts, particularly for a matter as complex as the Kilmore East bushfire proceedings, is a difficult, lengthy and costly process.

Deciding what level of judicial intervention is appropriate in the choice and briefing of experts is difficult. Associate Justice Zammit identified a number of factors that she considers important when managing experts prior to the trial, including:

- The role the expert evidence in the proceedings, and how important they would be to the critical findings;

- The number of experts likely to be called;

- The matters and issues the experts would be addressing to be sure that the evidence given matched what the Court was going to need to make a final determination;

\footnotetext{
${ }^{39}$ Interview with solicitor A, above n 18.

${ }^{40}$ Ibid.
} 
- Ensuring that the parties would have sufficient warning about all of the expert evidence to be given at trial;

- Ensuring the experts were aware that their responsibility was to the Court, not their clients;

- Ensuring the experts had sufficient direction to produce evidence that would genuinely assist the Court. ${ }^{41}$

These factors are a useful starting point for thinking about what sort of intervention by the Court is necessary. Nevertheless, her Honour warned against being "overly prescriptive" in how experts should be managed because "it will always be fact specific and will always turn on the nature of the case and the issues" being dealt with.

This raises an important question: could the choice of experts be made more efficient and fair through more significant intervention by the Court? Both Justice Forrest and Associate Justice Zammit thought that increased control would probably have been beneficial. Associate Justice Zammit said from her experience in the Kilmore East bushfire proceeding she would recommend that more "front end management about the type of witnesses, their expertise and the issues to be considered" occur earlier rather than later. ${ }^{42}$ Justice Forrest said that limiting the autonomy of parties may have made the trial more just and effective by reducing expert bias. He thought it was:

... inevitable because of the close contact between the lawyers and the experts over many months, indeed years in this case, that the expert, notwithstanding his or her desire to be independent, is inevitably consciously or subconsciously taking on the cause of [the party that retained them].43

His Honour said that this was "as good a reason as any for courts to contemplate ... the exercise of power to appoint experts ourselves or alternatively, to have parties agree as to joint reports [...] free from influence by the lawyers." 44 He noted that while it is necessary for each case to be treated according to its merits, "it is singularly important to endeavour to reduce the number of experts and to endeavour to narrow the issues", and thought that the Civil Procedure Act 2010, if utilised, "should go a long way to furthering those aims." 45

\footnotetext{
${ }^{41}$ Interview with Associate Justice Zammit, above n 23.

${ }^{42}$ Ibid.

${ }^{43}$ Interview with Justice J. Forrest, above n 27.

${ }^{44}$ Ibid.

${ }^{45}$ Ibid.
} 
The barristers and solicitors interviewed were sceptical about the value of the Court choosing experts. This was for a number of reasons. First, they did not think that biased experts were a real problem in the choice of experts. They did not accept that they deliberately selected 'partisan' experts, and so saw intervention to prevent it as unnecessary. One solicitor was adamant that their aim in finding experts was not to find one who said the right thing, but rather to find the very best expert to find the correct answer. He said that this was because "we regard it as inevitable that if they are not up to scratch, it will become clear." $46 \mathrm{He}$ also disputed the idea that a biased expert was in any way helpful or desirable for a party:

We take the exact opposite view - the most harmful thing an expert can do is indicate an unprincipled preference for your client's case. It becomes immediately apparent that they are an advocate more than they are an expert, and they are permanently damaged in terms of their standing with the court. [...] [F]rom our point of view I would disqualify as an expert anyone who during the interview processes was tending to tell us what they think we want to hear.

[...]

We want to avoid the experience where the expert turns around and says "that's what I thought you wanted to hear" even though they know in their heart of hearts that's not the right answer - well, that's disaster because based on the foundation that you think you've got a respectable case from the expert evidence point of view, you've told your client to organise themselves to [proceed with] the case $[\ldots]$ and you find yourself in a completely compromised position. So, our inclination is anyone who is in that interview process who obviously is trying to tell us what we want to hear, they are out straight away. We have no interest in engaging them. ${ }^{47}$

He said that is not always easy to know when an expert is modifying their opinion to suit your case, explaining that " $[t]$ he problem is some of these disciplines are so involved it is very hard for you as a practitioner to work out when they are being slightly intellectually flexible and when they are not." 48

One of the barristers interviewed was a little more circumspect, but came to a similar conclusion. He said that "any expert is naturally going to be inclined to some extent to be an advocate for the party calling them" but that "in large litigation [...] parties are usually fairly sensible and try and go for the best expert [...] rather than for the best advocate, on the basis that the best advocate is

\footnotetext{
${ }^{46}$ Interview with solicitor A, above n 18.

${ }^{47}$ Ibid.

${ }^{48}$ Ibid.
} 
just simply going to be unravelled." 49 In addition, he said that the adoption of expert codes of conduct had disciplined experts, and that this meant that it was not as much of a problem as it used to be. 50

The parties have a strong interest in choosing the best experts whose evidence will survive the trial process. If the expert evidence is particularly important to a case, they can devote more resources to find the right experts. One barrister explained that the parties are "usually likely to go off and search for the right type of experts, even internationally, whereas a court appointed experts it is difficult to see that you would go off to the United States or the Imperial College London and get your expert." 51

An added difficulty for the court controlling or intervening into expert choice is that sometimes not enough is known about the subject matter of the case to make an appropriate expert selection. One barrister said that:

I still think the judges frequently do not have enough information at a pre-trial stage, and it's not practical to expect them to get enough information, at the pre-trial stage, to be able to make the level of nuanced decisions that the parties know are going to be [required].

\section{$[\ldots]$}

The problem rears its head when you get to trial, because if the court has stopped a party from leading a particular point, and as the evidence comes through at trial it turns out the party was right to be pressing that point, it's then on the court's head that something has gone wrong. That is a less happy situation than when it is on a party's head for something going wrong. ${ }^{52}$

The effort the parties put into finding experts probably reflects, in part, the size and significance of the Kilmore East bushfire proceeding. In smaller cases, a more interventionist court might make more sense. One solicitor said that:

Obviously, we are talking about substantial litigation. There may well be a case, efficiently run, where the court could - say it is a very standard [...] business valuation case, and we'll know the ten leading people in Victoria, and it doesn't require anyone of international standing to give evidence

\footnotetext{
${ }^{49}$ Interview with barrister B, above n 20

${ }^{50}$ Ibid.

51 Ibid.

${ }^{52}$ Interview with barrister A, above n 20.
} 
on that question. [...] So I think the answer to [whether the court should control the number of experts] has to reflect that the cases can be of substantially different scale and complexity. ${ }^{53}$

Similarly, one barrister said that "in a relatively straightforward case" it could work for a judge to be "quite imperative" in terms of what was going to be allowed with experts, but that this was very difficult in novel cases. ${ }^{54}$ Other participants were more open to the idea of the Court limiting the number of experts. One solicitor said that in "large and complex proceedings there may be a case for the Court limiting the number of experts" but that the Court would have to be careful "to ensure that the parties have a genuine opportunity to present their case consistent with their own views as to what expert evidence is required." 55 He said that the difficulties with expert evidence in the Kilmore East bushfire proceeding was not due to the number of experts, but rather "the evolution of the volume, breadth, complexity and most significantly the timing of the expert reports introduced into the proceeding." 56

\section{Briefing experts}

The parties had autonomy in how they briefed their experts. The parties were required to disclose to each other the engagement letters to experts, which showed what experts they proposed calling, and the questions they proposed to ask. The legal practitioners supported this requirement. One solicitor explained:

Most parties observed that appropriately, [but] some parties then sought to negate the contents in the written instructions, and obviously they had just handed over a whole lot of documents and gave verbal instructions, so it is capable of being worked around. But, personally I found it useful, and that was the first instance that a judge had ordered it, and we have since replicated it in other cases. You have to overlook 'small issues' like privilege in the instructions, but if you just do it the parties tend to go along, and we've done it in subsequent cases and it is good practice. ${ }^{57}$

Associate Justice Zammit said requiring the parties to exchange all of their letters of instruction before they were sent to the experts ensured that they were "comparing apples with apples".58 However, it may not have been enough; despite this intervention, she said one of the difficulties in

\footnotetext{
${ }^{53}$ Interview with solicitor A, above $\mathrm{n} 18$.

${ }^{54}$ Interview with barrister A, above $\mathrm{n} 20$. Barrister B made a very similar point.

${ }^{55}$ Interview with solicitor B, above $\mathrm{n} 28$.

56 Ibid.

${ }^{57}$ Interview with solicitor A, above n 18.

${ }^{58}$ Interview with Associate Justice Zammit, above n 23.
} 
the expert conferences was that the experts were not aware what the other experts had been instructed to investigate. ${ }^{59}$

One barrister thought that enforcing transparency at an early stage benefited the parties and the proceeding. ${ }^{60} \mathrm{He}$ said that this was more useful than the Court truncating what the experts are engaged to do:

I think the more useful route was to regard that exchange of questions as an opportunity of each party to get an idea of what the opposing expert was likely to be covering, and possibly adjust their own question so that they were trying to ensure that the experts' reports didn't pass like ships in the night. 61

He added that:

The fact that the court was prepared to [...] order the parties to be transparent about the way the experts engaged was really useful, because it meant that the parties in their correspondence sort of knew that it was going to come out in the open pretty quickly so you might as well just deal with it candidly straight up. That helped a lot. It meant there were exchanges of information about the experts, there were exchanges of the questions, you had to give notice to the other side of all the material that was made available to your expert, so people could constantly be ensuring that their experts were aware of the likely enquiries being made by the opposing experts. And, when there were problems, we could raise it with the court quickly, so that helped a lot. 62

He said that there could be further benefits in more significant involvement by the court in the framing of questions for experts:

I think there is a lot of potential for that kind of approach to be developed a bit - where perhaps the court might spend some time itself interrogating the questions, not necessarily to say yes or no, but for the judge to express some views as to whether it seems like a sensible question, [...] whether it is appropriately focussed, and [...] to have that discussion in court with the benefit of the judge's input [...] would perhaps have helped the parties on both sides [...] to work on the questions and maybe reframe them more precisely. [...] [T] he more that the experts can be briefed with the same questions, the better the reports hopefully will meet each other head on. 63

\footnotetext{
${ }^{59}$ Ibid.

${ }^{60}$ Interview with barrister A, above n 20.

${ }^{61}$ Ibid.

${ }^{62}$ Ibid.

${ }^{63}$ Interview with barrister A, above n 20.
} 
The other barrister said he thought it was unnecessary to control the questions asked of the experts or require a common list of questions. Instead, it was "probably sufficient that there is transparency about the parties each knowing how the other experts have been retained and the questions they have been asked." 64 He said that this would be enough to make sure the reports were "matching in terms of addressing each other's issues and making sure that nothing comes out of left field." $65 \mathrm{He}$ said was a real risk in trying to control the questions that the parties put to their experts too early in the proceeding as the science can evolve and any "unnecessary rigidity" can impede this. ${ }^{66}$ If the Court does want to impose some common questions for the experts to answer, he said it should occur just before the expert evidence phase of the trial starts because everyone is much better informed at that stage. ${ }^{67}$

One solicitor did not think that the disclosure in the proceeding was sufficient. He said the lack of transparency about how the experts briefed by other parties were conducting testing "introduced significant complexity to the expert evidence that was ultimately led in trial." 68 He said that the introduction of one expert witness in particular was uncontrolled, with the expert going beyond the material to which he was called to respond and the evidence itself emerging quite late in the proceeding. ${ }^{69}$ He said these were matters were "within the knowledge and upon the instructions" of one of the other parties, and "capable of alternate pre-trial management."70 He contrasted this from other significant evidentiary complexity caused by "the rolling investigations" of various matters during the expert conferences, which was in his view "more properly a product of the expert conferences and less readily containable." 71

He said another difficulty faced by the experts of the parties was that they started with different evidence. The Court had ordered that there were to be no witness statements for the technical lay witnesses in the proceeding, and the solicitor explained that this "impacted upon [our] ability to assess the scale of the trial and the complexity of the evidence that would ultimately be led and which would need to be responded to" ${ }^{72}$ He said that a significant proportion of the critical evidentiary material that would normally be contained in these witness statements was only provided to his party a few days before it was to be adduced in trial. It was therefore impossible to

\footnotetext{
${ }^{64}$ Interview with barrister B, above n 20.

${ }^{65}$ Ibid.

${ }^{66}$ Ibid.

${ }^{67}$ Ibid.

${ }^{68}$ Interview with solicitor B, above n 28 .

${ }^{69}$ Ibid.

${ }^{70}$ Ibid.

${ }^{71}$ Ibid.

72 Ibid.
} 
brief the experts with this material, leaving his party at a "significant forensic disadvantage." $73 \mathrm{He}$ said that at least some of the material that came before the Court in this way would have been "more efficiently raised and considered by the experts during the conclave process." 74

One way of reducing the likelihood of this occurring might be to meet with the experts earlier in the proceeding. Associate Justice Zammit suggested that it might be useful to have the lawyers and expert witnesses in a case management conference before they prepared their reports:

[...] so that they get to hear from the Court what issues the Court considers are important; they get to hear from the Court right from the beginning what their role is as expert witnesses in a trial, that their obligation is not to the client but to the Court; where they're given time to think about the issues that need to be addressed, given the liability issues that are alive and, again, where everybody's there hearing it from the Court right at the beginning so that when we get to the conclaves or even the reports, everybody's coming along having at least understood what information the Court might need. ${ }^{75}$

The interviews with participants show a clear difference in opinion between the judges and the legal practitioners. Both Justice Forrest and Associate Justice Zammit thought that if they had exercised more control over the number and choice of experts, it would have improved the effectiveness of the expert evidence. However, if partisan experts and the volume of expert evidence is not seen as a problem, then intervention is an unnecessary limitation on the capacity of the parties to run their case. There was consensus that there should be more transparency in how parties briefed their experts. It seems that in the right circumstances, a case could benefit from the presiding judge working more closely with the parties to decide how the experts should be briefed by assisting with framing questions and ensuring that the information that forms the basis for the expert reports is available to all experts reporting on the one issue. However, there is always a risk of the Court exercising too much control over the case and preventing the parties calling the experts that would best assist with the factual issues in dispute.

\section{Case management conferences}

One notable feature of the proceedings was the extensive use of case management conferences prior to the commencement of the trial. The conferences were conducted by either Justice Forrest or Associate Justice Zammit, or both together, and were attended by the barristers and solicitors of

\footnotetext{
${ }^{73}$ Ibid.

${ }^{74}$ Ibid.

${ }^{75}$ Interview with Associate Justice Zammit, above n 23.
} 
the parties. The conferences were substantially more informal than traditional directions hearings and instead of occurring in a courtroom, were held in a conference room where all the participants sat around a large table.

Justice Forrest said they were "extraordinarily beneficial", explaining that the informality of the process meant that it was much easier to get agreement between the parties, and to discuss "mundane matters as well as matters of [...] principle." 76 His Honour added that:

The impact and the informality of the process is significant because it enables you to discuss with the lawyers on a first name basis exactly how the case is progressing. [...] this is particularly the solicitors who become far more involved in the case management conferences, are far more forthcoming. [...] Often they know a lot more about the procedural aspects or the administrative aspects of the case than do counsel. ${ }^{77}$

Associate Justice Zammit was also convinced of the value of the case management conferences. Her Honour explained that as directions hearings involved parties giving submissions about the position of the parties, they made it more difficult for collaborative decision-making. In contrast, case management conferences allowed for an informal process for the parties to share their views, and work out with each other and the Court how best to manage the case. ${ }^{78}$ Her Honour said that:

I found it a really useful tool in terms of the parties formulating processes, formulating steps that had to take place, timelines, things which we can do in a directions hearing, but given the complexity of the case management conference was a very good tool. ${ }^{79}$

Associate Justice Zammit said the informality of the conferences was particularly helpful:

My observation was that $[\ldots]$ as it was not just counsel addressing the Court [but also the] solicitors, [who] have the real running and day to day conduct of the file (and previously being a solicitor, perhaps that was something I was acutely conscious of), [...] contributed in a way that they just do not when you are in Court and they have got counsel as their advocate. So [it] was inclusive of everybody working on the trial. That was a real positive. I thought it allowed people to share views without, perhaps, the fear that they are going to be shut down, or being embarrassed, because it was, the whole idea of it was for us to be able to test ideas and come up with practical solutions.

\footnotetext{
${ }^{76}$ Interview with Justice J. Forrest, above n 27.

${ }^{77}$ Ibid.

${ }^{78}$ Interview with Associate Justice Zammit, above n 23.

${ }^{79}$ Ibid.
} 
It allowed me to not be in a role of "I am here to decide things" but rather "I am here to help you", and to really share with them my views on how it might be done. [...] It was a team approach as opposed to a party approach. [...] We didn't invite written submissions, we did not invite the usual reams of folders and I think that made it a lot easier and far more pleasurable for people to participate in. ${ }^{80}$

Increased involvement of the solicitors made the process more inclusive. Associate Justice Zammit said solicitors are often more used to dealing with each other as they have to have ongoing relationships, and as a consequence can be less adversarial than barristers. ${ }^{81}$ It "ensured that those people who ultimately had to answer to the client participated" in the Court's decision-making process. ${ }^{82}$

Associate Justice Zammit pointed out that this informal approach succeeded despite the fact that the case was bitterly fought at times. She recounted that during one of the discovery applications, one of the senior solicitors was put in the witness box and cross examined for over one day, and that there were many subsidiary proceedings on privilege, trespass to land and other matters. ${ }^{83}$ Nevertheless, the parties managed to cooperate in the case management conferences concerning the expert witnesses. ${ }^{84}$

Justice Forrest said that case management conferences were a "far more effective tool" than a directions hearing for some matters, and that a mix of the two procedures worked well. ${ }^{85} \mathrm{He}$ explained:

[We] used a mix of case management conferences and directions hearings generally depending upon what we thought the issues were likely to be. The case conferences were used a lot to flesh out problems with timing, flesh out problems with delivery of material. [...] Directions hearings were used more for at times matters of procedural principle, as well as some nuts and bolts [issues]. ${ }^{86}$

Justice Forrest said having Associate Justice Zammit involved in the case conferences was useful for two reasons. First, her Honour was able to make rulings in some of the case conferences, and

\footnotetext{
${ }^{80}$ Ibid.

${ }^{81}$ Ibid.

${ }^{82}$ Ibid.

${ }^{83}$ Ibid.

${ }^{84}$ Ibid.

${ }^{85}$ Interview with Justice J Forrest, above n 27.

${ }^{86}$ Ibid.
} 
second it gave her an insight into how the trial was progressing, enabling her to better intervene at a later stage. ${ }^{87}$

The solicitors saw the value of case management conferences. One solicitor said the most useful aspects of the process was reducing the need for lengthy and costly legal documents:

I'm personally not interested in huge affidavits on interlocutory applications and submissions. They are woefully inefficient. [The parties in Kilmore East] adopted a template which was extremely useful in case management conferences [...]. It was a template to identify the issue and set out the parties views on each issue. What it removed was formal applications, most of which are entirely unnecessary. Some are absolutely necessary, but a lot of them aren't. It removed wasted supporting affidavits. It removed submissions and responding submissions and further submissions, all of which are elaborate and expensive and ultimately inutile. What it lead people to do was simply state a position in half a dozen lines or less on each issue, allowed the trial judge to quickly see "right, we have four out of five parties on agreement on issue one, one party has this point to make, let's have it out". 88

He said that such an approach would still be possible in a directions hearing, but that case management conferences had a different emphasis that was helpful:

[...] a directions hearing implies a degree of formality with applications in a conventional way. A case management conference implies it is a management discussion, so [it requires the parties to] talk about the issues and roughly [their] position $[\ldots]^{89}$

Further, he said that directions hearings require an amount of work that is "often disproportionate" to the value that is extracted:

We literally set aside the four or five days leading up to the directions hearing for submissions and affidavits, most of which are historic footnotes by the time you actually get to the directions hearing. The less of that you can have the better, and I thought we did that quite effectively in the case management conference. ${ }^{90}$

The other solicitor said that in general they were a "useful mechanism for progressing the pre-trial issues in relation to expert witnesses" but "where they involve contested issues it is preferable to have the formality and levels of proof required by directions hearings." 91 The informality of the

\footnotetext{
${ }^{87}$ Ibid.

${ }^{88}$ Interview with solicitor A, above n 18.

${ }^{89}$ Ibid.

90 Ibid.

${ }^{91}$ Interview with solicitor B, above $\mathrm{n} 28$.
} 
conferences was "found to be productive". ${ }^{92}$ Speaking more generally, he said the involvement of the Associate Judge was a "good idea" in "very complex litigation of this scale" but that there should be a mechanism to allow the parties to raise matters critical to the proceedings arising from pre-trial matters directly with the trial judge. ${ }^{93}$

The barristers interviewed were sceptical about the difference that the case management conferences made to the proceedings. One acknowledged that it worked "very well" but said he thought the "only difference between a case management conference and a directions hearing was that in a case management conference he called me by my first name, and then in the directions hearing it was Mr [...]." 94 He said it was the informal style of Justice Forrest and Associate Justice Zammit and the level of experience of the participants that was important, and noted that this had an impact in directions hearings as much as case management conferences. ${ }^{95}$ However, he said the case management conference format does differ from a directions hearing as it:

[...] lends itself more to a free-flowing discussion [and that] having conversations about these issues rather than a sequence of people making submissions and submissions in response and then submissions in reply, [...] is a much better way of doing it. 96

Additionally, he saw merit in allowing the solicitors to actively participate in the conference because it saved time as it allowed them to be immediately consulted and give their opinion on matters within their field of expertise. ${ }^{97}$

He said what was crucial was that the court remained very involved throughout the pre-trial stage of the proceeding, and that this was possible with a directions hearing or a case management conference. This meant it had much better information about the proceeding, which in turn made the control the court exercised more informed and more useful. He also said court involvement in the process holds "the parties to a much greater discipline in terms of the need to be sensible in what they do, otherwise you get all of the usual, perfectly proper, litigation tactics." 98

The other barrister said that he did not find the case management conferences more advantageous than directions hearings. ${ }^{99} \mathrm{He}$ said the personality of the judges was much more important, and

\footnotetext{
92 Ibid.

${ }^{93}$ Ibid.

${ }^{94}$ Interview with barrister A, above n 20.

95 Ibid.

96 Ibid.

${ }^{97}$ Ibid.

${ }^{98}$ Ibid.

${ }^{99}$ Interview with barrister B, above n 20.
} 
how they decided what "directions were necessary for getting the thing on for trial, in a way that was accommodating to the pressures that both parties were facing." 100 Further, he said that the formality of the directions process was sometimes better in multi-party cases because "if you're all sitting around a long board table, sometimes it can be a bit more imprecise." 101 However, he said that this was a "subjective position" and that "different counsel and different judges will have their own views of the world."102

\section{PRE-TRIAL MANAGEMENT: CONCLUDING REMARKS}

The Court in the Kilmore East bushfire proceedings was not particularly interventionist in the management of experts prior to trial. With the notable exception of case management conferences, the court took a fairly standard approach in dealing with expert evidence. The parties had almost complete autonomy over which experts they retained to provide evidence. Justice Forrest and Associate Justice Zammit thought that if the Court had been more hands-on in the selection and briefing of experts, the overwhelming volume of expert evidence might have been reduced. This in turn would have made the trial run more efficiently. But would it have been more just?

The interviews with the parties illustrate the risks of treating this approach as a panacea to problems arising from the volume of expert evidence. The account one solicitor gave of the considerable effort he and his team undertook to find the best experts raises the question of the resources necessary for the Court to replicate that task. Moreover, it would be challenging (to say the least) for the Court to navigate disputes between experts about the appropriate methodology for developing their evidence, as well as the inevitable disputes between the parties and any procedural issues. Judges are, for the most part, not equipped at the beginning of a complex proceeding like the Kilmore East bushfire proceeding to make determinations about expert evidence that could see lines of enquiry in a case shut down. Therefore, any intervention by a court must be done with full attention to the risks involved.

This is not to say that some intervention is not useful. It would certainly be possible in some cases to impose a limit on the experts called on a particular issue, and in some situations it will be necessary to ensure the costs generated in the pursuit of expert evidence are not overwhelming or disproportionate. This, in fact, is an obligation of the court, the lawyers and the parties under the

\footnotetext{
${ }^{100}$ Ibid.

101 Ibid.

102 Ibid.
} 
Civil Procedure Act 2010.103 There is, after all, always the possibility of making an application for leave to admit more evidence if it becomes clear that it is necessary. A requirement for parties to share the issues and basis on which they are briefing their experts seems essential to ensuring that the expert reports address the same material. There are a number of ways this could be achieved, from sharing letters of instruction, to the Court helping the parties agree to a common document to be sent to all experts on a particular issue. Some flexibility in the procedure adopted by the Court to work through issues is also productive. Case management conferences were useful in this case, particularly when dealing with administrative issues amenable to consensus.

A just trial requires a balance between competing needs: the judgment needs to be based on the best information available, but the cost of gathering that information should not be so high, in terms of time or money, as to overwhelm the entire proceeding. This is also what the Civil Procedure Act 2010 mandates. It is not always an easy balance to strike, particularly at the beginning of a trial when so much is unclear. The different views of the participants in the Kilmore East Bushfire Proceeding are testament to the difficult decisions that confront a judge in such a case.

103 ss $24,65 \mathrm{~F}$. 


\section{APPENDIX}

\section{A. Section one: view from the Victorian bench}

The decision that judges have to make about how to manage experts prior to trial is a complex one. The contemporary perspective of judges in Victoria about pre-trial management of experts was sought to complement the views set out above from the literature. In order to capture this information, and to help understand how different judges saw pre-trial management, four judges of the Victorian Supreme Court with experience in managing expert evidence were interviewed in late 2014. It is clear from these interviews that their views differed about when intervention is necessary, the considerations that should be taken into account when dealing with experts prior to trial, and the value of case management conferences. It shows that much depends on the particular style of the judge and, even more importantly, the particular circumstances of the case.

\section{When is intervention necessary?}

Some judges prefer the traditional approach of leaving it to the parties, and others were supportive of an interventionist approach. Justice Hargrave was firmly in favour of the Court being involved from the beginning of the trial:

Expert evidence, if it is not properly managed, wastes a lot of time and the sooner the experts get on the same page, especially before mediation, the more prospect there is of either settling the case or at least reducing the issues in the case. ${ }^{104}$

His Honour said that parties had a tendency to only ask enough questions of their expert witnesses based on their client's view of the facts, and that meant that there often needed to be "proper consultation, almost mediation" between the parties to determine what the questions should be. ${ }^{105}$ In contrast, Justice Beach explained that his preferred approach is not to intervene until it becomes apparent that the approach of the parties is not working:

I think all parties should be given an opportunity to run the case they want to run and in the way they want to run it until it becomes apparent that this isn't working, it's either not working for them, or it will consume too many court resources and it's not working for us. So, I give them all the autonomy they can handle up until I'm unhappy with the way they're doing it, and then I put a stop to it and do something else. ${ }^{106}$

\footnotetext{
${ }^{104}$ Interview with Justice Hargrave (6 October 2014, Supreme Court of Victoria, Melbourne)

105 Ibid.

${ }^{106}$ Interview with Justice Beach (2 September 2014, Supreme Court of Victoria, Melbourne)
} 
Justice Beach was more circumspect about the value of proactive pre-trial management of experts. He explained that while proactive management could sometimes be helpful it "really does depend". He said:

There's always the possibility that you'll do something that'll cause someone to say, 'Oh, I need to get another expert' or, 'I need to get expert evidence on a topic that I hadn't thought was in play but clearly is in play'. The overriding message, if I had a message to give you, is that there's no 'one size fits all'; every case is different, dependent on its own issues, dependent on the people who are running it and their resources and dependent upon the quality and competence of their lawyers. ${ }^{107}$

Justice Almond said that while it was difficult to assess the impact of pro-active pre-trial management of expert evidence, he suspected that it was effective at reducing the number of issues requiring expert evidence at trial. He said that it can help to ensure the parties had turned their minds to whether they actually needed experts and encourage them to be more "confined and considered" in their approach.

The Judges were generally supportive of limiting the number of experts in certain circumstances. Justice Almond said that the parties should be limited in the number of experts they call to give evidence on particular issues:

There is no point in having three experts come along to say the same thing, and to hope that having three experts saying the same thing will give three times the weight to the evidence. In nuanced cases where the views of multiple experts could contribute to the calculus of decision-making, different considerations would apply. But often one suitably qualified expert is sufficient. ${ }^{108}$

However, Justice Beach noted that it is not often that such a limitation is necessary. He explained:

[...] it's not often that you actually have to limit someone. It costs a lot of money to retain an expert. Sensible parties and sensible lawyers don't go retaining numerous experts just for the sake of it. If you detect that a party seems to be retaining more experts on the one topic, my first question for them in a directions hearing is why; if you're just witness-shopping, your first choice didn't produce what you liked, your second choice didn't produce what you like, what makes you think your third or your fourth or your fifth? Put a stop to it. And if you don't put a stop to it, I'll put a stop to it. You're not going to be allowed to just call repetitive evidence on the one topic. ${ }^{109}$

Justice Croft said he would only limit the number of experts a party would call "reluctantly", and that he would want to be very sure that the Court was not "actually removing part of the subject

\footnotetext{
107 Ibid.

${ }^{108}$ Interview with Justice Almond (13 October 2014, Supreme Court of Victoria, Melbourne)

${ }^{109}$ Interview with Justice Beach (2 September 2014, Supreme Court of Victoria, Melbourne).
} 
matter of the expert evidence, because you might have a whole lot of different aspects that are subject to expert evidence." 110

In contrast, Justice Hargrave said that parties should "absolutely" be limited to one expert per issue, and that he found it difficult to think of a case where more than this would be necessary. ${ }^{111}$

\section{General considerations for the management of experts prior to trial}

Each judge was careful to point out that the scale, complexity and volume of expert evidence in any given court case depends on the facts of that case. It can be difficult for a judge to assess at an early stage what approach is appropriate to manage this expert evidence when all the relevant facts are not clear. Justice Hargrave said the ease of assessing at an early stage the role that experts would play in the proceeding depended on whether the case was on a managed list.112 If it was, he said it would be apparent very soon because the judge will ask questions that would identify the major issues of the case. He said that the sooner and the more the judge knows about the experts being used in the proceeding, the better. ${ }^{113}$ Justice Croft said that it was usually "pretty clear right from the start" from the nature of the case and the directions process. ${ }^{114}$ For example, expert evidence is very likely to play a central role in a case about a hydro-electric scheme or a tunnel failure. 115

Justice Beach indicated that it was sometimes possible to assess the number of experts in the trial at an early stage, particularly if the lawyers and judges have a considerable amount of experience in dealing with the type of case. ${ }^{116}$ However, in other cases it can be much more difficult, particularly where the defence have taken an old-fashioned approach and said little more in their pleadings apart from 'not admit, deny.' Justice Beach noted it was possible to intervene to make the lawyers tell the Court what experts they planned to call, but was cautious about recommending such an approach:

[...] that's a pretty heavy-handed way to manage a case, and at least managing a major torts case. I never wanted to do anything that might provoke the parties into thinking 'Oh my, we've got to get more experts $[\ldots]^{\prime}$, you know, 'the judge thinks this is a heavy expert case, well, it must be, so

\footnotetext{
${ }^{110}$ Interview with Justice Croft (14 October 2014, Supreme Court of Victoria, Melbourne).

${ }^{111}$ Interview with Justice Hargrave (6 October 2014, Supreme Court of Victoria, Melbourne).

112 Ibid.

${ }^{113}$ Ibid.

${ }^{114}$ Interview with Justice Croft (14 October 2014, Supreme Court of Victoria, Melbourne).

115 Ibid.

${ }^{116}$ Interview with Justice Beach (2 September 2014, Supreme Court of Victoria, Melbourne).
} 
therefore we'll get some experts', so, as I say, good lawyers will expose how many experts of the scale of expert evidence issues very early on, but less good lawyers will take longer. ${ }^{117}$

Justice Almond said that the judge should encourage parties to consider whether "an expert is really necessary", and if so, have the parties identify which issues will require expert evidence.118 In addition, he said he would try to determine early on whether there would be any issues before trial that would impact on the "smooth running of the trial and the hearing of the expert evidence", such as challenges to qualifications of an expert, so these could be dealt with prior to the trial. ${ }^{119}$ Furthermore, he said that he would emphasise from the very beginning that an expert's duty was to the court, not the party that retained him or her. He explained:

Expert evidence is compromised unless the expert has a deep and fundamental understanding of that proposition. [...] Experts need to understand the fundamentals behind such a regime in order to make any worthwhile contribution. ${ }^{120}$

Justice Beach explained that along with the issues in the trial, and the complexity of those issues, it was critical to consider the level of sophistication of the parties and their legal representatives. His Honour said:

I have managed trials from what could be said to be from two extreme positions: one, where I heavily regulated the management of the trial because it was long and complicated and had been going for more than 20 years, [...] and I had no great faith in some of the lawyers, [it] was such a mess that I was entirely prescriptive. And then at the other end of the spectrum, I had the Abalone class action, which had some of the best and most efficient lawyers in it, and when I went to manage it and make what might be called 'prescriptive orders', they said "Stop, don't make any orders, trust us and it'll be okay and we'll come back and see you every few months [...] and if you don't like what we are doing at any time you can jump in and make prescriptive orders". It's the best trial I've ever conducted; it was so efficient. Probably more than anything, [the most important consideration is] who are the lawyers and how good are they and how good are they at managing their own problems, because the judge intervening is a pretty blunt instrument because the judge never knows, you never know a tenth of what good lawyers know about their own case, and if they're good lawyers and they're experienced, they also know how to manage it. ${ }^{121}$

\footnotetext{
${ }^{117}$ Ibid.

${ }^{118}$ Interview with Justice Almond (13 October 2014, Supreme Court of Victoria, Melbourne)

119 Ibid.

${ }^{120}$ Ibid.

${ }^{121}$ Interview with Justice Beach (2 September 2014, Supreme Court of Victoria, Melbourne)
} 
Justice Almond also noted that the level of sophistication of the parties was an important consideration:

I tend to be quite liberal in the sense that, if parties want to run their cases in a particular way, I will generally not stand in the way. But that's to be qualified by saying that if they're well represented, experienced litigants I'm likely to give more autonomy than if they're inexperienced and need guidance. If they're self-represented, I am likely to be more closely engaged in evaluating the need for expert evidence and the type of expertise required.122

Justice Hargrave said that while the pre-trial management of experts always had to occur on a case-by-case basis, the Judge and the parties should "think very carefully about what questions the experts should be asked to give an opinion on." 123 He has found that the "biggest problem is when the parties slant the questions in a particular way for their own expert, and [the Court] ends up with two expert reports which don't address the same issues." 124 He explained that:

I think it is very important that experts, if they're going to prepare their own individual reports to form a joint report, both are expressing opinions on the same questions which accommodate both sides of the equation and the questions are broad enough to encompass the range of possible factual findings. 125

He further said that where the parties cannot agree as to what questions to ask the experts, it is better for the Court to be involved to settle any differences, and that sometimes it is a "good thing to go straight to a joint report because it saves a lot of money. It saves people getting into entrenched positions." 126

As can be seen from the above, when judges are deciding on how best to manage experts prior to the trial, they must be highly responsive to the nature of the case before them, as well as the competency and experience of the parties. There is no 'one size fits all' solution for the management of experts, but rather a series of factors that should be taken into account.

\section{Case Management Conferences}

There were differing views about the value of using case management conferences to manage experts instead of directions hearings. Justice Hargrave said that in his personal view there was no difference between a case management conference and a long directions hearing, and preferred the

\footnotetext{
${ }^{122}$ Interview with Justice Almond (13 October 2014, Supreme Court of Victoria, Melbourne)

${ }^{123}$ Interview with Justice Hargrave (6 October 2014, Supreme Court of Victoria, Melbourne)

124 Ibid.

125 Ibid.

126 Ibid.
} 
latter approach. ${ }^{127} \mathrm{He}$ said that a directions hearing ensures that the judge is in control, and can progress through the issues one by one, resolving disputes as they arise.

Justice Beach was not convinced that the informality of case management conferences was helpful to the efficient and just management of proceedings. He explained that he generally preferred directions hearings:

There's obviously good things that can be achieved in case management conferences, but there's got to be discipline. There's got to be an agenda. I'm not of the school of thought that says everybody in the room gets a chance to talk on every topic on the agenda because, at some point, you start saying why are we doing this. I much prefer to focus the parties and say, 'Look, this is the next issue, what are the competing positions, why shouldn't I, after hearing short submissions from each of you, rule and make an order?' and let's move on. ${ }^{128}$

Justice Beach said he thought the discipline and formality of directions hearings caused people to prepare more fully as it made the stakes of the particular hearing more apparent. ${ }^{129}$ Justice Almond was also sceptical about the value of case management conferences, explaining that in his experience they "ultimately end up as directions hearings." $130 \mathrm{He}$ also said that the discipline of the directions hearing process was helpful as it forced the parties to refine their proposals in writing. ${ }^{131}$

\footnotetext{
${ }^{127}$ Interview with Justice Hargrave (6 October 2014, Supreme Court of Victoria, Melbourne)

${ }^{128}$ Interview with Justice Beach (2 September 2014, Supreme Court of Victoria, Melbourne)

129 Ibid.

${ }^{130}$ Interview with Justice Almond (13 October 2014, Supreme Court of Victoria, Melbourne)

${ }^{131}$ Ibid.
} 


\section{B. Section two: methodology}

The primary source of material for this research project was gathered in interviews with some of the participants of the Kilmore East bushfire proceeding and some judges of the Supreme Court of Victoria. The interviews were conducted in late 2014 and early 2015 in person and by email. The judges selected were either involved in the proceeding (Justice Forrest and Associate Justice Zammit) or were chosen as they represented a range of different views about the management of expert evidence (Justice Beach, Justice Croft, Justice Almond and Justice Hargrave). The participants from the Kilmore East bushfire proceeding interviewed were selected to ensure that the research took account of both the plaintiff and defendant sides, as well as covering the different roles within the proceeding. To this end, two barristers and two solicitors were interviewed. They agreed to be interviewed on the basis that they would remain anonymous due to the sensitive nature of some of their comments, accordingly all identifying information has been removed from their answers.

Interviews in person were semi-structured and the questions were reasonably broad (for example, "When did the scale of the trial and the number of experts that would be needed become apparent?" and "What were the benefits, if any, of case management conferences to directions hearings in the management of expert witnesses by the Court?"). Interviews conducted by email or letter were by response to questions provided to the interviewees. The research project has some obvious limitations: it was not possible to interview all the judges of the Supreme Court or all the participants in the Kilmore East bushfire proceeding. It does not in any way assess the experience of the many plaintiffs, whose tragic experiences were the basis of the case. It only tells the story of one case, and the case itself was very unusual. This paper is not intended to be a source of comprehensive empirical data, but rather to ensure the experience of the Court is recorded and that any lessons that were learnt during the proceeding are captured for posterity. It is hoped that this record will be of value to other judges of the Supreme Court of Victoria, as well as in other jurisdictions, and to legal practitioners. One of the aims of the project was to better understand what methods of managing expert evidence were used by the court and how they perceived by those who were using them - and the Kilmore East bushfire proceeding was a good opportunity to assess some of these issues. 


\section{University Library}

\section{- M M I N E R VA A gateway to Melbourne's research publications}

Minerva Access is the Institutional Repository of The University of Melbourne

Author/s:

McKenzie, S

Title:

Pre-trial management of expert evidence in the Kilmore East bushfire proceeding

Date:

2016-04-13

Citation:

McKenzie, S. (2016). Pre-trial management of expert evidence in the Kilmore East bushfire proceeding. Supreme Court of Victoria.

Persistent Link:

http://hdl.handle.net/11343/91566 